\title{
Low litter cover, high light availability and rock cover favour the establishment of Ailanthus altissima in forests in southern Switzerland
}

\author{
Simon Knüsel ${ }^{1,2}$, Marco Conedera', Harald Bugmann², Jan Wunder ${ }^{1,3}$ \\ I Community Ecology, WSL Swiss Federal Institute for Forest, Snow and Landscape Research, a Ramél 18, CH- \\ 6593 Cadenazzo, Switzerland 2 ETH Zurich, Department of Environmental Sciences, Institute of Terrestrial \\ Ecosystems, Forest Ecology, Universitätstrasse 16, CH-8092 Zürich, Switzerland 3 School of Environment, The \\ University of Auckland, Auckland 1020, New Zealand
}

Corresponding author: Simon Knüsel (simon.knuesel@wsl.ch)

Academic editor: Ingo Kowarik | Received 24 April 2019 | Accepted 16 May 2019 | Published 10 June 2019

Citation: Knüsel S, Conedera M, Bugmann H, Wunder J (2019) Low litter cover, high light availability and rock cover favour the establishment of Ailanthus altissima in forests in southern Switzerland. NeoBiota 46: 91-116. https://doi. org/10.3897/neobiota.46.35722

\begin{abstract}
Future forest composition is uncertain in many areas due to climate change. The spread of non-native species adds to these uncertainties, particularly in forests recently colonised by novel tree species. To anticipate future forest composition, and thus the provision of ecosystem services, a thorough understanding of the factors influencing the establishment of non-native tree species is essential. We studied the presence and abundance of regeneration of Ailanthus altissima (Mill.) Swingle in 89 plots on a regular grid in three sites in southern Switzerland to determine the main drivers of its establishment. All sites are located in abandoned, i.e. currently unmanaged stands of Castanea sativa Mill. Propagule pressure is caused by single mature $A$. altissima that colonised the area ca 40 years ago. We found high rock cover, low litter cover and high light availability to be the most important predictors for the presence of $A$. altissima regeneration, whereas its abundance was positively influenced by high light availability, low litter cover and high browsing on regeneration of competing species. However, the presence models performed much better than the abundance models. Interestingly, the most important factors favouring the establishment of A. altissima in recently undisturbed sites were found to be similar in a nearby site after a severe forest fire, which suggests a similar establishment strategy after a disturbance as in recently undisturbed forests. Based on our results we expect a further expansion of the species in lowland forests currently dominated by $C$. sativa, likely controlled primarily by light availability.
\end{abstract}

\section{Keywords}

Ailanthus altissima (tree of heaven), browsing, Castanea sativa (sweet chestnut), Gap Light Index (GLI), invasive tree, light availability, litter cover, non-native tree, propagule pressure

Copyright Simon Knüsel et al. This is an open access article distributed under the terms of the Creative Commons Attribution License (CC BY 4.0), which permits unrestricted use, distribution, and reproduction in any medium, provided the original author and source are credited. 


\section{Introduction}

Many forest ecosystems are expected to face compositional changes as a consequence of climate change, the introduction and spread of novel tree species, or interactions thereof (Lindner et al. 2010; Hickler et al. 2012). As shifts in tree species composition are first detectable in the regeneration layer (Grund et al. 2005; Moser et al. 2010; Fisichelli et al. 2013; Rigling et al. 2013), a thorough understanding of the factors underlying the successful establishment of novel tree species is crucial to anticipate future community development. Knowledge on the possible future forest composition is a prerequisite for evidence-based, anticipatory management decisions (Lindner et al. 2014), which may enable a continuous provisioning of forest ecosystem services (Gret-Regamey et al. 2013; Seidl et al. 2016). This is particularly important in forests that have only recently started to be colonised by non-native trees, i.e. where the future development is often highly uncertain.

The establishment of non-native tree species has mainly been studied in disturbed forest ecosystems (e.g., Maringer et al. 2012). On the one hand, because colonisation rates are generally slow in closed-canopy forests due to extended periods without gap formation and thus colonisations are difficult to detect and quantify at early stages (Martin et al. 2009; Essl et al. 2011; Wangen and Webster 2006). On the other hand, the majority of non-native tree species that are able to establish and spread outside of their native range are shade intolerant (Martin et al. 2009) and thus depend on large scale disturbances for their establishment. However, also disturbance dependent non-native trees have been able to persist in patches of undisturbed forests. Prunus serotina Ehrh., for example, can maintain a short-lived seedling bank, which enables the species to reach the canopy after gap formation (Closset-Kopp et al. 2007; Vanhellemont et al. 2009). Furthermore, Acacia dealbata Link, generally considered to be light demanding, was found to be able to grow below the canopy of native trees in south-central Chile (Fuentes-Ramírez et al. 2011).

In this study, we focus on the establishment of the early-successional tree species Ailanthus altissima (Mill.) Swingle. Its spread in forest ecosystems has often been associated with disturbances induced by forest management (Call and Nilsen 2003; Radtke et al. 2013; Berg et al. 2017; Rebbeck et al. 2017) or natural processes (Xi 2008; Maringer et al. 2012; Kasson et al. 2013). Despite the positive association of A. altissima with disturbance, the species also proved to be capable of establishing in forests lacking a large scale disturbance by virtue of its fast juvenile height growth (Knapp and Canham 2000; Martin et al. 2010; Knüsel et al. 2016). However, the environmental factors underlying the successful establishment of $A$. altissima in recently undisturbed forests remained largely unexplored. To shed light on these factors, we studied its generative regeneration in recently unmanaged lowland forests of southern Switzerland that started to be colonised by $A$. altissima following the general abandonment of the forests dominated by Castanea sativa Mill. in the 1950s. Specifically, we focused on the current distribution frontier where only few canopy A. altissima are present, which enabled us to study generative regeneration rather than vegetative sprouts that typically grow faster and can persist in shadier conditions (Kowarik 1995; Knüsel et al. 2016). We addressed the following research questions: 
i) What are the most important environmental factors that drive the presence and abundance of regeneration of $A$. altissima in recently undisturbed forests?

Once identified, we compared these factors with the environmental drivers of the post-fire establishment of $A$. altissima in the same study region (Maringer et al. 2012), leading to the second research question:

ii) What are the key differences in the environmental drivers of the establishment of A. altissima in disturbed versus recently undisturbed forests?

Knowledge on key differences in the establishment requirements of $A$. altissima in forests after a disturbance versus recently undisturbed forests may facilitate predictions on the spread of the species.

\section{Materials and methods}

\section{Study species}

Ailanthus altissima is a dioecious early successional tree species originating from China that was brought to Europe around the 1740 s as an ornamental tree (Kowarik and Säumel 2007). The spread of $A$. altissima has often been associated with natural disturbances (Xi 2008; Maringer et al. 2012; Kasson et al. 2013) or disturbance caused by forest management (Call and Nilsen 2003; Radtke et al. 2013; Berg et al. 2017; Rebbeck et al. 2017). Radtke et al. (2013) found frequent clear-cuts in coppice forests to favour the establishment and spread of $A$. altissima in northern Italy, while the time since the last timber harvest was the best predictor of $A$. altissima presence and density in state forests in Ohio, USA (Rebbeck et al. 2017). Moreover, natural disturbances such as fire (Maringer et al. 2012), windthrow (Xi 2008) or insect defoliation (Kasson et al. 2013) were found to lead to an increase in the abundance and/or the area colonised by A. altissima. In particular, light availability (Knapp and Canham 2000; Maringer et al. 2012; Martin et al. 2010; Berg et al. 2017; Rebbeck et al. 2017) and nutrient availability (Soják and Löffler 1988; Berg et al. 2017) were found to increase the growth and abundance of $A$. altissima regeneration.

\section{Study area}

The study was conducted in the sweet chestnut ( $C$. sativa) forests of southern Switzerland. The climate in the study area is characterized by a mild average annual temperature of ca $12.7{ }^{\circ} \mathrm{C}$ and a mean annual precipitation of $1862 \mathrm{~mm}$ (climate normal 1981-2010, MeteoSwiss station Locarno-Monti, $383 \mathrm{~m}$ a.s.l.). A large amount of precipitation falls in short and heavy spells during the growing season $(1023 \mathrm{~mm}$ 
from May to September) followed by a relatively dry period in winter. The soils are classified as haplic podzol (cryptopodzol) on crystalline bedrock (Blaser et al. 2005).

The studied forests used to be dominated by $C$. sativa, which was introduced by the Ancient Romans more than 2000 years ago (Tinner et al. 1999) and intensively cultivated in monocultures as coppice forests or orchards (Conedera et al. 2004). The cultivation of C. sativa dropped in the 1950s as a consequence of a general abandonment of agriculture and the simultaneous spread of the chestnut blight (Cryphonectria parasitica (Murr.) Barr.). In the following decades, chestnut forests were increasingly colonised by native (Fraxinus spp., Tilia spp., Prunus spp.) and non-native tree species (Robinia pseudoacacia L., A. altissima, Paulownia tomentosa (Thunb.) Steud.) facilitated by the generally low competitiveness of $C$. sativa (Conedera et al. 2001; Pividori et al. 2005), which was further weakened by repeated outbreaks of pathogens such as the ink disease (Phytophthora spp.; Prospero 2017), the chestnut blight (Rigling and Prospero 2018), and since 2009 the arrival of the chestnut gall wasp (Dryocosmus kuriphilus Yasumatsu; Gehring et al. 2017).

\section{Study sites}

We selected three study sites in southern Switzerland based on an occurrence map of A. altissima (Gurtner et al. 2015). We looked for sites at the current distribution frontier of the species with no vegetative regeneration. All sites (named Locarno, Sementina, San Vittore) are situated in the chestnut belt at elevations ranging from 400 to $550 \mathrm{~m}$ a.s.l. Their slopes are facing SW to SE with an average inclination of $70^{\circ}\left( \pm 18.0^{\circ}\right.$ standard deviation, Fig. 1$)$. In all three sites, C. sativa comprises the largest fraction of basal area (77-98\%), followed by deciduous Quercus spp. (0-15\%). All other species have a basal area $<5 \%$ (Betula pendula Roth, Robinia pseudoacacia L., Tilia spp., Fraxinus spp., Prunus avium (L.) L., Sorbus aria (L.) Crantz, Paulownia tomentosa Steud., Populus tremula L., Populus alba L., A. altissima). All studied forests used to be managed as coppices except for a small part (ca $1 \mathrm{ha}$ ) of the site in San Vittore, which was managed as a chestnut orchard. In all three sites, no management has taken place since the 1950s apart from occasional cuttings of single trees or small forest patches $(<0.2 \mathrm{ha})$.

To get an overview of the colonization history as well as the existing propagule pressure of $A$. altissima in the study sites, we searched for and mapped all seedbearing female $A$. altissima within the boundary of the study sites and in a buffer of approximately $300 \mathrm{~m}$ around the studied forests. Of all accessible female trees, an increment core was extracted at a height of ca $1.3 \mathrm{~m}$ to determine their age. In the site Locarno, only a single female tree was found with an age of ca 18 years. In Sementina, the oldest of the four female trees was ca 27 years old, while the other three were only ca 15 years old. In the site San Vittore, several adult and at 


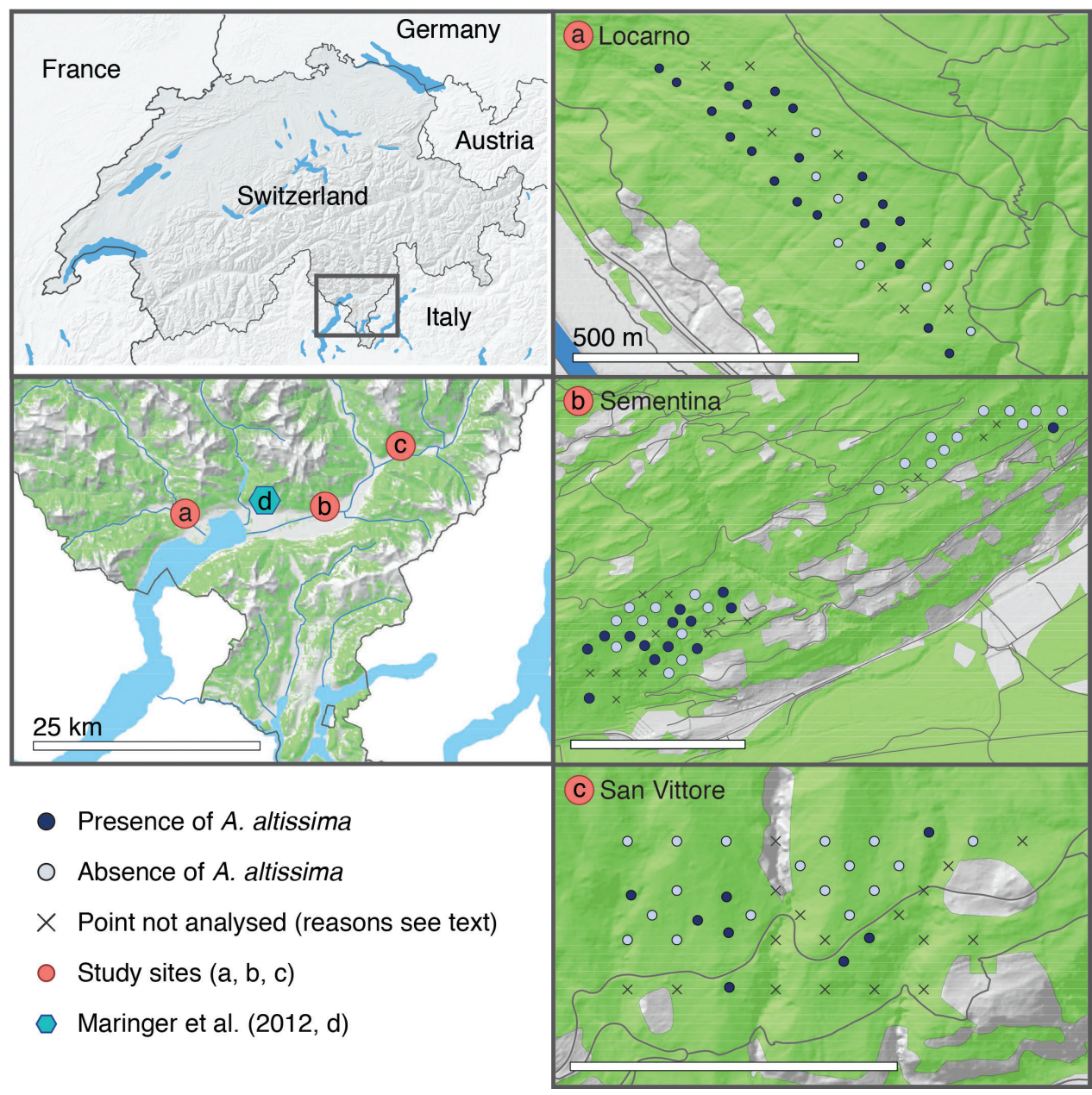

Figure I. Study area and study sites. Study area in southern Switzerland (left column) and selected study

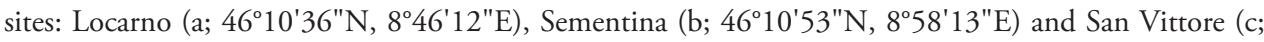
$46^{\circ} 14^{\prime} 19^{\prime \prime} \mathrm{N}, 9^{\circ} 04^{\prime} 46^{\prime \prime} \mathrm{E}$; right column with scale bars representing $500 \mathrm{~m}$ ). (d) Represents the study area analysed by Maringer et al. (2012) on the establishment of non-native species after a forest fire, which was used for comparison in this study.

least 40-years-old $A$. altissima trees that grew along the road crossing the study site (Fig. 1) were girdled in 2010 and felled in winter 2014 (Luca Plozza, pers. comm.). About 10 adult trees remained in the forest, of which the oldest female tree was ca 40 years old. Although we searched for seed-bearing female $A$. altissima during the sampling (summer 2015) and in the following winter after leaf shedding, it cannot be ruled out entirely that further and yet undiscovered seed-bearing trees exist in inaccessible parts around the study sites. 


\section{Sampling design}

We applied a systematic sampling design that was centred on $A$. altissima. An adaptation was necessary to obtain a sufficient number of sampling points with regeneration of A. altissima, as the studied forests are located at the distribution frontier where the species occurs at low densities only. To this end, we placed a regular grid with a mesh size of $50 \mathrm{~m}$ over all three study sites and defined potential sampling points at the nodes of the grid. At each of these points we searched for $A$. altissima saplings $(>40 \mathrm{~cm}$ tall and $<12 \mathrm{~cm} \mathrm{DBH}$ ) in a circular area of $800 \mathrm{~m}^{2}$ (ca $16 \mathrm{~m}$ radius) around the sampling points. Plants smaller than $40 \mathrm{~cm}$ were not considered to avoid individuals that had germinated in the year of the field survey (Knüsel et al. 2016). This resulted in 44 sampling points with saplings of $A$. altissima in the vicinity (later referred to as presence points) and 45 without (later referred to as absence points), i.e. a total of 89 sampling points (Fig. 1). These numbers already exclude several sampling points that were inaccessible $(n=15)$, experienced heavy management $(n=8$, i.e. below a power line and close to a building inside the forest), or were close $(<10 \mathrm{~m})$ to a forest road $(n=9)$. In addition, six sampling points were excluded because of mature $A$. altissima $(\mathrm{DBH}>12 \mathrm{~cm})$ in the $800 \mathrm{~m}^{2}$ circle, which may support conspecific regeneration via root grafts (O’Neal and Davis 2015).

At the absence points, two nested, slope-corrected circular plots with sizes of 100 and $200 \mathrm{~m}^{2}$ were temporarily installed at the nodes of the grid. At presence points, in contrast, the nested plots were not installed at the nodes of the grid, but were moved to have the nearest $A$. altissima sapling in the centre.

A range of environmental variables were then measured in each plot. First, the light environment was recorded at the plot centre with a hemispherical photograph (Canon EOS 50D camera with a Sigma EX DC $4.5 \mathrm{~mm}$ fisheye lens). The photograph was taken horizontally at a height of $1.7 \mathrm{~m}$ to avoid shading by small regeneration. If the A. altissima sapling representing the plot centre (later referred to as central A. altissima) at presence points was taller than $1.7 \mathrm{~m}$ it was bent to the forest floor to avoid selfshading. In addition, the age of the central $A$. altissima was assessed by counting growth units (Heuret et al. 2003) for individuals $<6$ years and by taking an increment core or a stem disc at $40 \mathrm{~cm}$ height for older individuals. Furthermore, we excavated the central A. altissima to verify its seed origin in case a mature $A$. altissima occurred within $20 \mathrm{~m}$. All excavated central $A$. altissima originated from seeds.

In the $100 \mathrm{~m}^{2}$ plot, we surveyed ground cover as well as seedlings $(10-40 \mathrm{~cm}$ tall) and saplings ( $>40 \mathrm{~cm}$ tall) of all tree species. Percentage cover of bare soil (later referred to as mineral soil cover), litter, herbs and shrubs (later referred to as vegetation cover), coarse woody debris and vegetation-free rock (later referred to as rock cover) were assessed visually in $10 \%$ classes. Ground cover values were assessed so that they added up to $100 \%$. For tree seedlings, the species and the presence of recent (i.e., last three years) browsing damages were noted. For saplings, we additionally recorded height, $\mathrm{DBH}$ and damage by fraying (only for saplings $>130 \mathrm{~cm}$ tall).

In the $200 \mathrm{~m}^{2}$ plot, we assessed stand structure and signs of management (i.e., presence of tree stumps). For all trees and coppice shoots or stools $(\mathrm{DBH}>12 \mathrm{~cm})$, $\mathrm{DBH}$, height and the vitality class following Tinner et al. (2010) were recorded. 


\section{Establishment models}

\section{Model types}

We used two types of multiple regression models to analyse $A$. altissima establishment. First, we used logistic models (LOG) to analyse the presence or absence of $A$. altissima saplings. Second, we used negative binomial models (NB) to analyse the abundance (number) of $A$. altissima saplings (see Methods S1 for details).

\section{Explanatory variables}

The light environment was characterized by the Gap Light Index (GLI), which integrates diffuse and direct irradiation over a growing season. GLI was calculated from the hemispherical photographs with the program Hemisfer (www.schleppi.ch/hemisfer; Schleppi et al. 2007). As an additional measure, we quantified canopy closure, i.e. the proportion of the sky covered by vegetation when viewed from a single point (Jennings et al. 1999; Gonsamo et al. 2013). Canopy closure was further used as a single explanatory variable in a separate simple LOG model, since it represents a more intuitive and easily obtainable measure of the light environment that can be estimated visually by practitioners. Based on this simple model, we calculated a threshold canopy closure value that best differentiated the presence or absence of $A$. altissima saplings by optimizing for the sum of sensitivity and specificity based on the ROC curve with the $R$ function coords in the $R$ package $p R O C$ (Robin et al. 2011).

Three of the five assessed ground cover variables, mineral soil, litter, and rock cover were used as explanatory variables (Table 1 ). Vegetation cover was excluded due to a variance inflation factor (VIF) $>5$, calculated with the viffunction in the $R$ package car (Fox and Weisberg 2011). Coarse woody debris was excluded due to the small variance in the data (Table 1) and a lacking ecological justification, since no regeneration growing on woody debris was found (personal observation). Furthermore, we approximated propagule pressure by the minimal distance of each sampling point to the nearest seed-bearing tree (later referred to as seed source). The distance to the next seed source was calculated using ArcGIS. In addition, we characterised stand density by the total sum of living basal area $\left(\mathrm{m}^{2} \mathrm{ha}^{-1}\right)$ of all trees on the plot above $12 \mathrm{~cm} \mathrm{DBH}$. Due to the high browsing pressure on competing tree species (but not on $A$. altissima), we calculated an average proportion of browsed co-occurring species (excluding $A$. altissima) for each sampling point. Finally, we analysed interactions of saplings of $A$. altissima with saplings of other tree species. To this end, we selected the number of seedlings and the number of saplings of the four most abundant species as additional explanatory variables. Moreover, we selected the sum of living basal area of the four tree species with the highest total basal area to analyse interactions with canopy tree species. The number of other tree species' seedlings and saplings, as well as the living basal area were not used in the process of model selection, but were only added to the most parsimonious models after model selection.

All continuous variables were standardized before running the models by subtracting the mean and dividing the result by the standard deviation. 
Table I. Environmental parameters recorded for the establishment models.

\begin{tabular}{lcc}
\hline Continuous predictors & Mean (SD) & Range \\
\hline Light environment: & $21(14.6)$ & $4-73$ \\
$\quad$ Gap light index (GLI) & & \\
Ground cover: & $15(12.4)$ & $0-52$ \\
$\quad$ Mineral soil cover (\%) & $32(20.8)$ & $0-85$ \\
$\quad$ Litter cover (\%) & $18(13.9)$ & $0-70$ \\
$\quad$ Rock cover (\%) & $5(6.1)$ & $0-32$ \\
$\quad$ Coarse woody debris cover (\%) & $29(24.7)$ & $0-92$ \\
$\quad$ Vegetation cover (\%) & & \\
Propagule pressure: & $127(65.1)$ & $15-303$ \\
$\quad$ Distance to seed source (m) & $36(21.3)$ & $5-121$ \\
Stand characteristics: & & \\
$\quad$ Basal area per plot $\left(\mathbf{m}^{2} \mathbf{h a}^{-1}\right)$ & $40(18.0)$ & $0-100$ \\
Browsing: & Levels & $\boldsymbol{n}$ \\
$\quad$ Browsed competitors $(\%)$ & Locarno & 29 \\
\hline Categorical predictors & San Vittore & 25 \\
\hline Site & Sementina & 35 \\
& & \\
\hline
\end{tabular}

Bold labels indicate predictors that were used for model selection.

\section{Model selection}

Starting with the eight selected variables (Table 1), we generated a full submodel set with the dredge function in the $R$ package MuMIn (Barton 2018). Three main models were chosen for reporting: (1) null model (later referred to as $\mathrm{NB}_{\text {null }}, \mathrm{LOG}_{\text {null }}$ ), (2) most parsimonious model of those models that differed by less than $2 \mathrm{AIC}_{\mathrm{C}}$ points compared to the model with the lowest $\mathrm{AIC}_{\mathrm{C}}$ score (later referred to as $\mathrm{NB}_{\text {pars }}, \mathrm{LOG}_{\text {pars }}$ ), (3) average of all models within $2 \mathrm{AIC}_{\mathrm{C}}$ points (later referred to as $\mathrm{NB}_{\text {avg }}, \mathrm{LOG}_{\text {avg }}$ ). All models within $4 \mathrm{AIC}_{\mathrm{C}}$ points as well as the average thereof can be found in Tables S1-S4.

For the averaging of all models within $2 \mathrm{AIC}_{\mathrm{C}}$ points, we used the zero method to compute parameter estimates (Burnham and Anderson 2002; Nakagawa and Freckleton 2010), where a parameter estimate of zero is added for a parameter not occurring in a model selected for averaging. In addition, a relative importance value for each explanatory variable occurring in at least one of the averaged models was calculated. It represents the fraction of models used for averaging in which a certain variable occurred.

\section{Model performance}

Goodness-of-fit of the models was assessed by comparing the most parsimonious models against the null model with a Chi-squared test. For the LOG models we further calculated AUC values with the $R$ package $p R O C$ (Robin et al. 2011) to quantify the predictive power of the models. As no similar measure exists for NB models, we computed the Pearson correlation of the observed number of $A$. altissima saplings versus the predicted number using $\mathrm{NB}_{\text {pars }}$. 


\section{Comparison with post-fire establishment}

To discriminate factors driving the establishment of A. altissima after a forest fire (Maringer et al. 2012) versus in recently undisturbed stands (this study, no forest management or other large-scale disturbances for the last ca 60 years), we reanalysed the data of Maringer et al. (2012). The authors studied the establishment of non-native species in plots affected by a forest fire four years before and in adjacent control plots (Maringer et al. 2012). The study was conducted in the same study region (Fig. 1).

In particular, we aimed at quantifying differences in ground cover and light availability in presence and absence points in this study and in fire affected plots in Maringer et al. (2012). Due to deviations in the sampling protocols we did not directly compare values between the studies, but used two-sided Wilcoxon tests instead to quantify differences within but not across the studies. Ground cover values have been assessed in a circle of $200 \mathrm{~m}^{2}$ size in Maringer et al. (2012) as opposed to a $100 \mathrm{~m}^{2}$ circle in our study. In addition, Maringer et al. (2012) assessed herb, fern and shrub cover separately. Hence, vegetation cover in this study (sum of herb and shrub cover) was compared to herb cover only of Maringer et al. (2012). Further, canopy closure in Maringer et al. (2012) was measured from eight photographs taken in subplots of the $200 \mathrm{~m}^{2}$ plot, whereas in our study it was calculated from a single hemispherical photograph taken at each sampling point.

\section{Results}

\section{Presence and abundance of regeneration}

The presence points were on average slightly closer to seed sources $(118 \mathrm{~m}$, $\pm 61.3 \mathrm{~m}$ standard deviation) than the absence points $(136 \mathrm{~m}, \pm 68.1 \mathrm{~m})$, however not significantly $(P>0.2)$. In the 44 presence points, a total of 243 saplings of A. altissima were recorded. They had a mean height of $224 \mathrm{~cm}( \pm 179.9 \mathrm{~cm})$, a mean DBH of $1.0 \mathrm{~cm}$, and a mean age of 4 years $( \pm 1.8 \mathrm{yr})$, with a maximum of 11 years. When present, $A$. altissima saplings often dominated the regeneration at the sampling point $(57 \% \pm 31.3 \%$ of all saplings, Table 2$)$. The four most abundant saplings of other species were C. sativa (total $=181), R$. pseudoacacia $(80)$, Fraxinus spp. (50) and S. aria (31).

In addition, we recorded a total of 188 seedlings of $A$. altissima, accounting on average for $16 \%( \pm 18.1 \%)$ of all seedlings at the presence points (Table 2$)$. The four most abundant seedlings of other species were Fraxinus spp. (total $=1560)$, Quercus spp. (1241), C. sativa (1186) and R. pseudoacacia (202).

Only $A$. altissima showed an increasing relative frequency of individuals with increasing height (Fig. 2). In contrast, the most frequent co-occurring species at the earliest stages, such as Quercus spp. and Fraxinus spp., featured a strong reduction in stem numbers with increasing height. 
Table 2. Presence and abundance of regeneration. Shown are seedlings $(10-40 \mathrm{~cm}$ tall $)$ and saplings ( $>40 \mathrm{~cm}$ tall and $<12 \mathrm{~cm} \mathrm{DBH}$ ) of $A$. altissima and the four most abundant co-occurring seedlings or saplings. Values are averages per sampling point, with standard deviations in parentheses.

\begin{tabular}{|c|c|c|c|c|c|}
\hline \multirow[t]{3}{*}{ Class } & \multirow[t]{3}{*}{ Species } & \multicolumn{4}{|c|}{ Sampling points } \\
\hline & & \multicolumn{2}{|c|}{ With $A$. altissima saplings } & \multicolumn{2}{|c|}{ Without $A$. altissima saplings } \\
\hline & & $\mathbf{n}^{*} \mathbf{h a}^{-1}$ & $\begin{array}{c}\text { proportion per } \\
\text { sampling point (\%) }\end{array}$ & $\mathbf{n}^{*} \mathbf{h a}^{-1}$ & $\begin{array}{c}\text { proportion per } \\
\text { sampling point }(\%)\end{array}$ \\
\hline \multirow[t]{5}{*}{ Seedlings } & A. altissima & $494(513)$ & $16(18.1)$ & $163(177)$ & $4(6.5)$ \\
\hline & Fraxinus spp. & $4023(11312)$ & $35(26.1)$ & $1082(1812)$ & $20(18.1)$ \\
\hline & Quercus spp. & $1161(1375)$ & $28(22.4)$ & $2146(3329)$ & $37(31.0)$ \\
\hline & C. sativa & $1068(1377)$ & $20(18.6)$ & $1912(3174)$ & $42(27.5)$ \\
\hline & $R \cdot$ pseudoacacia & $563(392)$ & $15(10.5)$ & $500(831)$ & $10(8.7)$ \\
\hline \multirow[t]{5}{*}{ Saplings } & A. altissima & $560(603)$ & $57(31.3)$ & - & - \\
\hline & C. sativa & $391(429)$ & $30(23.3)$ & $465(470)$ & $72(32.0)$ \\
\hline & $R \cdot$ pseudoacacia & $492(776)$ & $26(20.3)$ & $300(490)$ & $18(12.4)$ \\
\hline & Fraxinus spp. & $257(234)$ & $16(9.6)$ & $275(236)$ & $45(46.1)$ \\
\hline & S. aria & $500(693)$ & $23(31.6)$ & $229(138)$ & $46(29.1)$ \\
\hline
\end{tabular}

Proportions per sampling point are an average over all sampling points in which the respective species occur.

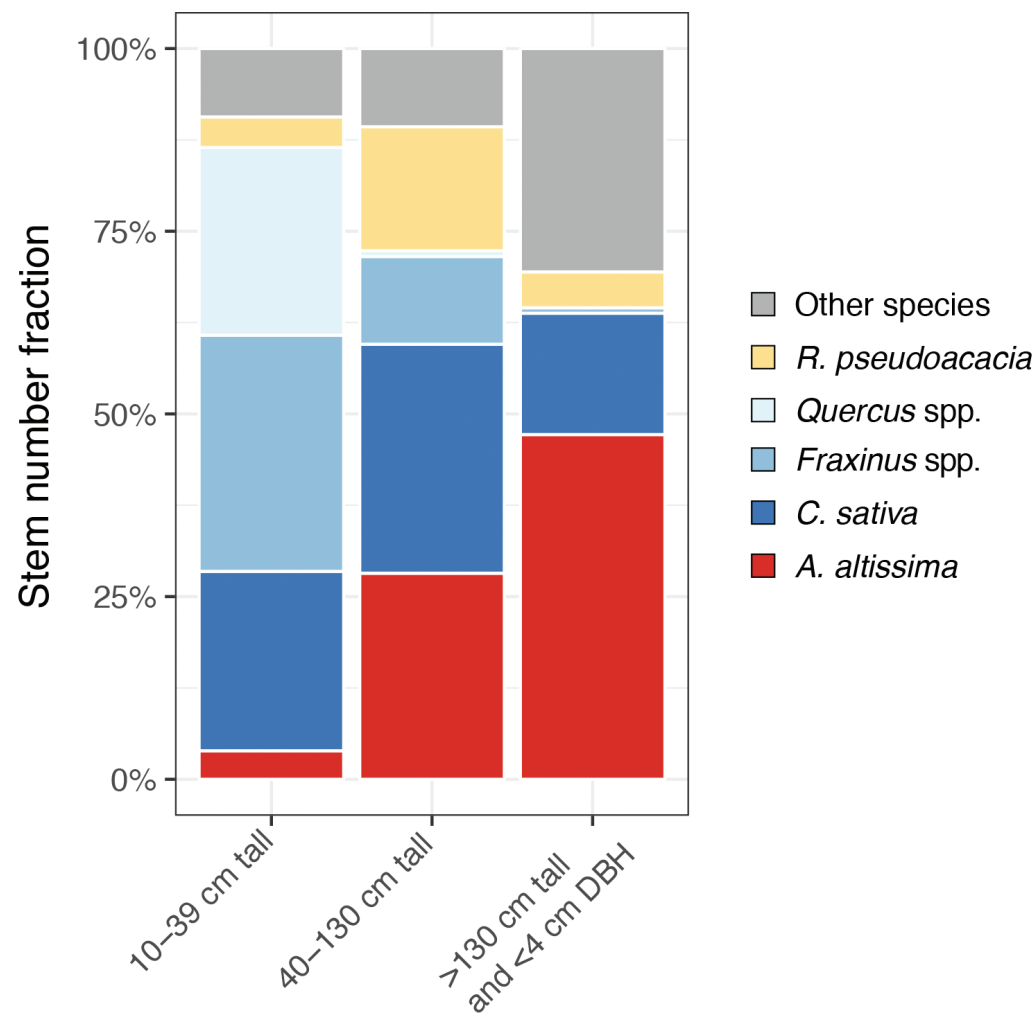

Figure 2. Fractions of stem numbers per species for three different height classes. Data were pooled from all three sites. 


\section{Establishment models}

\section{Drivers of $A$. altissima occurrence}

The occurrence of $A$. altissima saplings was positively $(P<0.05)$ affected by rock cover and negatively $(P<0.001)$ by litter cover in LOG pars $($ Table 3$)$. LOG pars fitted the data significantly better $(P<0.001)$ than $\mathrm{LOG}_{\text {null }}$ as indicated by a Chi-squared test. $\mathrm{LOG}_{\text {avg }}$ identified rock cover as the only significant variable $(P<0.05)$, which also had the highest relative importance. Additionally, LOG $_{\text {avg }}$ identified the GLI, distance to seed source, mineral soil cover and site as explanatory variables, which were not included in $L_{\text {pars }}$. However, only GLI and distance to seed source were included in a larger number of averaged models $(>60 \%)$. Both $L \mathrm{GG}_{\text {pars }}$ and $\mathrm{LOG}_{\text {avg }}$ had similar AUC values (0.88 and 0.91 , respectively).

Table 3. Results of the logistic models of the occurrence of $A$. altissima saplings. The null model $\left(\mathrm{LOG}_{\mathrm{null}}\right)$, the most parsimonious model $\left(\mathrm{LOG}_{\text {pars }}\right)$ as well as an average of all models $(n=8)$ within $2 \mathrm{AIC}_{\mathrm{C}}$ points $\left(\mathrm{LOG}_{\mathrm{avg}}\right.$ ) are shown. Significant predictors are written in bold, values in parentheses represent standard errors.

\begin{tabular}{|c|c|c|c|}
\hline & LOG $_{\text {null }}$ & LOG $_{\text {pars }}$ & LOG $_{\text {avg }}$ \\
\hline \multirow[t]{2}{*}{ (Intercept) } & -0.05 & -0.19 & 0.21 \\
\hline & $(0.21)$ & $(0.29)$ & $(0.65)$ \\
\hline \multirow[t]{2}{*}{ Rock cover (\%) } & & $0.74^{*}$ & $0.82^{*}$ \\
\hline & & $(0.36)$ & $(0.41)$ \\
\hline \multirow[t]{2}{*}{ Litter cover (\%) } & & $-1.86^{* * *}$ & -1.11 \\
\hline & & $(0.42)$ & $(0.71)$ \\
\hline \multirow[t]{2}{*}{ Gap Light Index (-) } & & & 0.92 \\
\hline & & & $(0.68)$ \\
\hline \multirow{2}{*}{ Distance to seed source (m) } & & & -0.44 \\
\hline & & & $(0.43)$ \\
\hline \multirow[t]{2}{*}{ Mineral soil cover (\%) } & & & 0.12 \\
\hline & & & $(0.25)$ \\
\hline \multirow[t]{2}{*}{ Site - San Vittore } & & & -0.19 \\
\hline & & & $(0.51)$ \\
\hline \multirow[t]{2}{*}{ Site - Sementina } & & & -0.52 \\
\hline & & & $(1.00)$ \\
\hline $\mathrm{AIC}_{\mathrm{C}}$ & 123.99 & 82.41 & - \\
\hline AUC & 0.50 & 0.88 & 0.91 \\
\hline \multicolumn{4}{|l|}{ Relative importance } \\
\hline Rock cover & & & 1.00 \\
\hline Litter cover & & & 0.87 \\
\hline Gap Light Index & & & 0.83 \\
\hline Distance to seed source & & & 0.69 \\
\hline Mineral soil cover & & & 0.27 \\
\hline Site & & & 0.26 \\
\hline
\end{tabular}


The three most important variables according to $\mathrm{LOG}_{\mathrm{avg}}$, i.e. rock cover, litter cover and GLI, showed significant differences $(P<0.01)$ between presence-and absence points (Fig. 3a, b, e, red boxes). In addition, vegetation cover, which was excluded from the models due to multicollinearity, was significantly higher $(P<0.01)$ at presence points (Fig. 3d). As a more intuitive measure, the light environment was additionally characterized by canopy closure (Fig. 3f). At a threshold value of $86 \%$ canopy closure, the highest correct classification rate could be achieved based on canopy closure alone (Fig. 3f, red dashed line).

\section{Drivers of $A$. altissima abundance}

According to $\mathrm{NB}_{\text {pars }}$, the abundance of $A$. altissima saplings was significantly positively affected by GLI and the percentage of browsed competitors, whereas litter cover had a

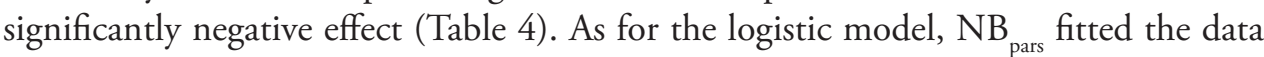
significantly better $(P<0.001)$ than $\mathrm{NB}_{\text {null }}$, but displayed a poor predictive power with a low correlation $(r=0.17)$ between observed and predicted numbers of $A$. altissima saplings (Fig. S1).

$\mathrm{NB}_{\text {avg }}$ identified the percentage of browsed competitors, GLI and litter cover as the most important variables as well, supplemented by mineral soil cover, total basal area and rock cover. However, the influence of total basal area and rock cover were marginal only (Table 4).

\section{Browsing and fraying}

Overall, $A$. altissima regeneration $(10-300 \mathrm{~cm}$ tall) experienced less $(P<0.01)$ browsing damage compared to the four most frequent other species (Fraxinus spp., C. sativa, Quercus spp. and $R$. pseudoacacia) and an average of all other species (Fig. 4).

Compared to the two species with most abundant saplings taller than $130 \mathrm{~cm}$ (C. sativa and $R$. pseudoacacia) as well as an average over all other species, $A$. altissima was frayed significantly less $(56 \% \pm 33 \%$ standard deviation, $P<0.05)$ than $C$. sativa $(81 \% \pm 27 \%)$ but did not differ significantly $(P>0.4)$ from $R$. pseudoacacia $(75 \% \pm$ $35 \%)$ or an average of all other species $(52 \% \pm 31 \%$, Fig. S2).

\section{Comparison with post-fire establishment}

Two of the three most important variables for the occurrence of $A$. altissima saplings identified in this study, litter cover and light availability, also differed significantly $(P<0.01)$ between presence- and absence points in a study conducted after a forest fire (Maringer et al. 2012, Fig. 3b, f). Mineral soil cover, in contrast, was significantly higher $(P<0.01)$ in presence points after fire (Maringer et al. 2012), but not in this 
a)

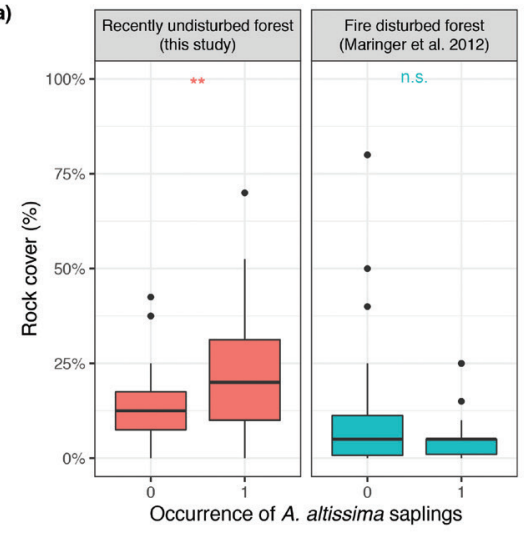

c)

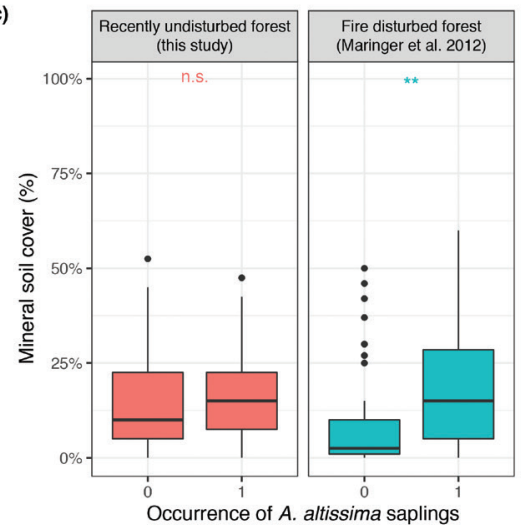

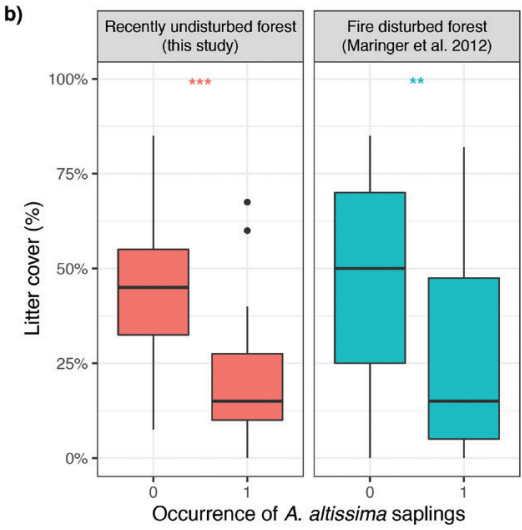

d)

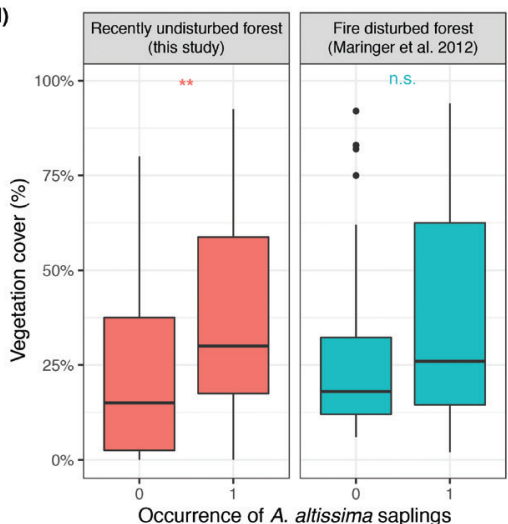

e)

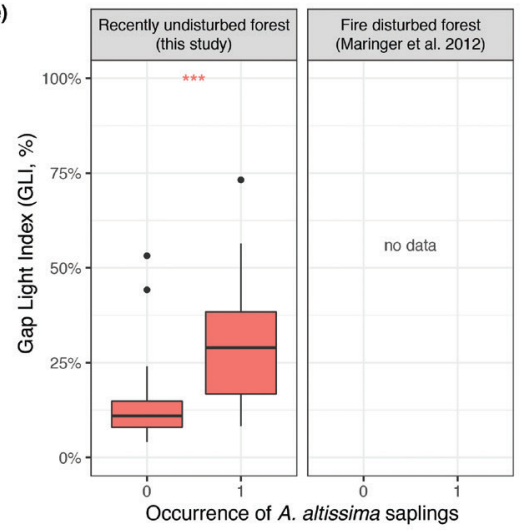

f)

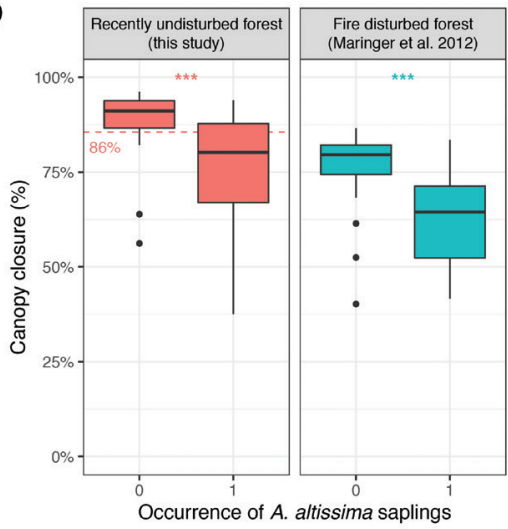

Figure 3. Comparison of ground cover $(\mathbf{a}-\mathbf{d})$ and light environment $(\mathbf{e}, \mathbf{f})$ between sampling points with or without saplings ( $>40 \mathrm{~cm}$ tall and $<12 \mathrm{~cm} \mathrm{DBH)} \mathrm{of} \mathrm{A.} \mathrm{altissima.} \mathrm{Values} \mathrm{originate} \mathrm{from} \mathrm{recently} \mathrm{undisturbed}$ forests (this study), and from a forest analysed four years after a fire (Maringer et al. 2012). The dashed line in (e) shows a threshold value that is optimized for sensitivity and specificity to distinguish sampling points with or without saplings of $A$. altissima in recently undisturbed forests. Asterisks indicate significant differences between sampling points with and without saplings of $A$. altissima $\left({ }^{* *} P<0.01,{ }^{* * *} P<0.001\right.$ ). See text for differences in the sampling procedure between this study and Maringer et al. (2012). 


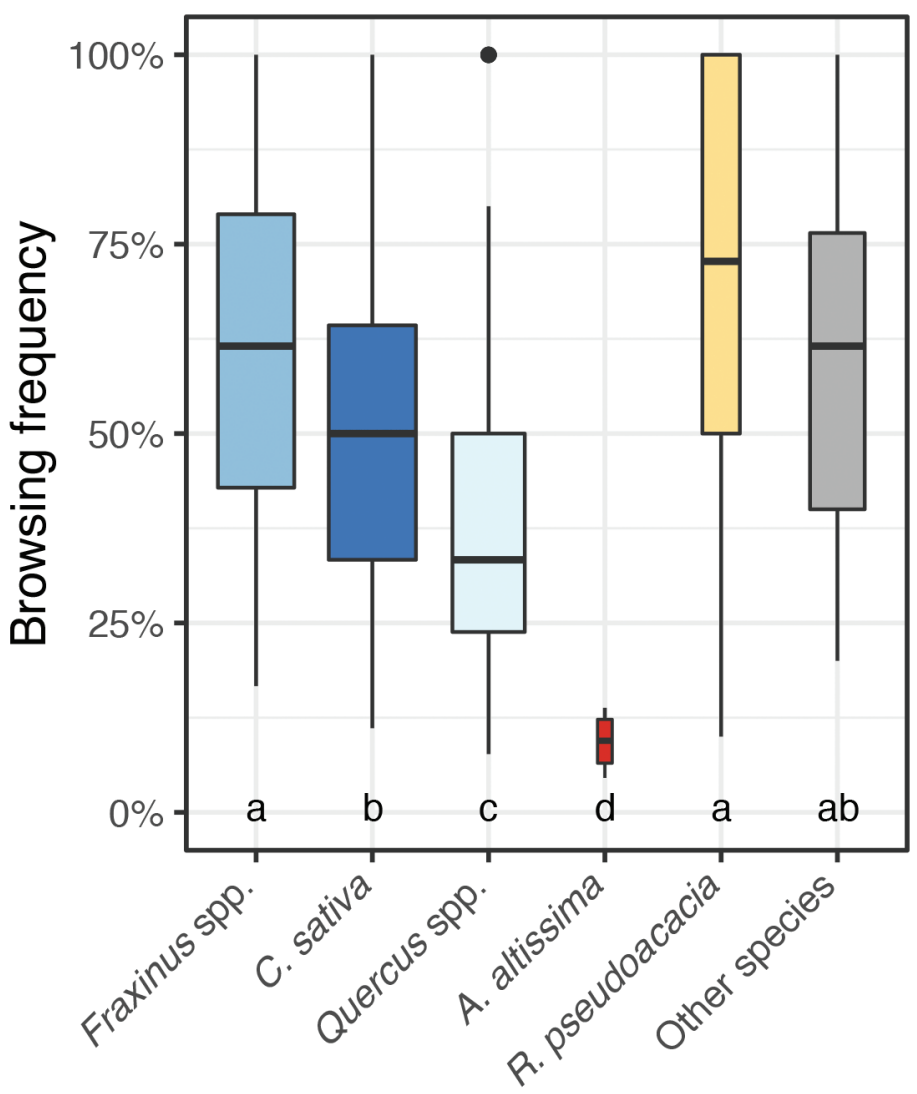

Figure 4. Proportion of browsed regeneration. Browsing damages were recorded on saplings $10-300 \mathrm{~cm}$ tall for the three most recent years. Widths of the bars are proportional to the number of individuals recorded $(n>360)$. Different lowercase letters indicate significant $(P<0.05)$ differences between proportions.

study (Fig. 3c). In addition, rock cover was generally lower in the area studied by Maringer et al. (2012) and did not differ significantly between presence- and absence points, while the difference was significant $(P<0.01)$ in this study (Fig. 3a). Moreover, vegetation cover was higher in presence points in both studies (Fig. 3d), but only differed significantly $(P>0.01)$ in this study.

\section{Interactions with other species}

The number of $A$. altissima saplings was significantly negatively $(P<0.05)$ correlated with the number of $S$. aria saplings only (Table S6). However, $S$. aria was merely present in 10 sampling points, with a maximum of 13 saplings at one sampling point (cf. Table 2). The three species with most abundant saplings (C. sativa, $R$. pseudoacacia and Fraxinus spp.), in contrast, were not significantly related $(P>0.2)$ to the number of $A$. altissima saplings. 
Table 4. Results of the negative binomial model of the number of $A$. altissima saplings. The null model $\left(\mathrm{NB}_{\text {null }}\right)$, the most parsimonious model $\left(\mathrm{NB}_{\text {pars }}\right)$ as well as a model average of all models $(n=6)$ within $2 \mathrm{AIC}_{\mathrm{C}}$ points $\left(\mathrm{NB}_{\text {avg }}\right)$ are shown. Significant predictors are written in bold, values in parentheses represent standard errors.

\begin{tabular}{lccc}
\hline & $\mathbf{N B}_{\text {null }}$ & $\mathbf{N B}_{\text {pars }}$ & $\mathbf{N B}_{\text {avg }}$ \\
\hline (Intercept) & $\mathbf{1 . 0 1}^{* * *}$ & $\mathbf{0 . 5 1 ^ { * * }}$ \\
& $(0.21)$ & $\mathbf{0 . 5 3}^{* *}$ & $(0.19)$ \\
Gap Light Index (-) & $(0.19)$ & $\mathbf{0 . 7 5 * *}$ \\
& & $\mathbf{0 . 7 0}^{* *}$ & $(0.26)$ \\
Browsed competitors (\%) & $(0.24)$ & $\mathbf{0 . 4 5}$ \\
& & $\mathbf{0 . 4 5}^{*}$ & $(0.18)$ \\
Litter cover (\%) & $(0.18)$ & -0.53 \\
& & $-\mathbf{0 . 6 4}$ & $(0.33)$ \\
Mineral soil cover (\%) & $(0.28)$ & 0.23 \\
& & $0.23)$ \\
Total basal area (m²ha') & & 0.05 \\
& & $0.13)$ \\
Rock cover (\%) & & 0.01 \\
& & $0.07)$ \\
AIC & & - \\
Relative importance & & \\
Gap Light Index & & 1.00 \\
Browsed competitors & 330.73 & 1.00 \\
Litter cover & & 0.89 \\
Mineral soil cover & & 0.61 \\
Total basal area & & 0.24 \\
Rock cover & & 0.11 \\
\hline
\end{tabular}

${ }^{* * *} P<0.001,{ }^{* *} P<0.01,{ }^{*} P<0.05$

The number of $A$. altissima saplings was positively $(P<0.001)$ correlated with the number of seedlings of $R$. pseudoacacia and Fraxinus spp., while there was no significant relationship $(P>0.5)$ with the other two most frequent seedling species, $C$. sativa and Quercus spp. (Table S5).

The amount of basal area of live trees of the four most prominent tree species (C. sativa, Quercus spp., B. pendula and $R$. pseudoacacia) at presence points did not show a significant relationship $(P>0.05)$ with $A$. altissima sapling density (Table S7).

\section{Discussion}

\section{Regeneration models}

Drivers of $A$. altissima occurrence

The occurrence of $A$. altissima saplings was mainly favoured by high rock cover, low litter cover and high light availability (Table 3). A beneficial effect of a high rock cover on the presence of $A$. altissima has not been found in other studies that analysed the 
establishment of the species in forests (Maringer et al. 2012; Radtke et al. 2013). However, A. altissima is known to thrive in ruderal urban sites (Celesti-Grapow and Blasi 2004; Kowarik and Säumel 2007) that partly resemble rocky forest patches. Rock cover has been suggested to reduce competition and serve as a refuge for early successional species (Frelich and Reich 2002), even more if they are drought tolerant (Plieninger et al. 2010). Both effects may partially explain the association of A. altissima with rocky forest patches.

The negative effect of litter cover for the occurrence and the abundance of regeneration of $A$. altissima may have been caused by a delay in germination and an increased invertebrate herbivory and seedling mortality, as found in an early successional site (Facelli and Pickett 1991; Facelli 1994). Similarly, Kostel-Hughes et al. (2005) found reduced robustness of seedlings that emerged from deep litter (ca $5 \mathrm{~cm}$ deep) in an experimental study, although there was no difference in the probability of emergence between different litter treatments (no litter, $1-2 \mathrm{~cm}$ and $\mathrm{ca} 5 \mathrm{~cm}$ deep litter).

As expected, light availability played a major role for the occurrence of the early successional $A$. altissima. Although the species is able to persist in low light levels for several years (Knapp and Canham 2000; Knüsel et al. 2016), most of the presence points experienced light levels above 10\% GLI (Fig. 3e). A study of Martin et al. (2010) conducted in forests in north-western Connecticut (USA) found that radial growth of $A$. altissima exceeded native regeneration at levels $>10 \%$ of full sunlight (GLI), but not at light levels below 3\%. However, we did not measure such low light levels in this study (Fig. 3e). Moreover, Huebner et al. (2018) found canopy closure of ca $85 \%$ and above to reduce the establishment probability for $A$. altissima. The threshold suggested by Huebner et al. (2018) also matches the 86\% canopy closure level found in this study (Fig. 3f, red dashed line), at which the probability of false positive and false negative classifications of $A$. altissima occurrence was minimal.

\section{Drivers of $A$. altissima abundance}

The models for the abundance of $A$. altissima saplings had a much lower predictive power than the occurrence models, which implies that the following interpretations represent tendencies only. While high light availability and low litter cover were also important for the density of $A$. altissima regeneration, rock cover did not influence sapling abundance. This might be related to the lower availability of suitable sites for establishment in rocky forest patches (Frelich and Reich 2002). In contrast, sapling density of A. altissima was positively influenced by an increased cover of mineral soil (Table 4, Fig. 3c), which is known to be an important factor for the establishment of many light-demanding early successional tree species (Shields et al. 2007; Zouhar et al. 2008), including A. altissima (Call and Nilsen 2003; Martin and Canham 2010). Furthermore, the observed high browsing pressure on competitors may have indirectly favoured the largely unbrowsed regeneration of $A$. altissima through reduced competition.

However, the distribution of tree species is determined not only by the availability of suitable microsites for their establishment, but also by seed production and dispersal 
(Nathan and Muller-Landau 2000; Turnbull et al. 2000). Limitations in propagule pressure are often particularly important for expanding non-native tree species (Pyšek et al. 2009; Terwei et al. 2013; Conedera et al. 2017; Sullivan and Franco 2017; Dyderski and Jagodziński 2018). Accordingly, the distance to the next seed source played a role for the occurrence of $A$. altissima (Table 3), which is in line with previous studies (Radtke et al. 2013; Höfle et al. 2014). Thus, a further increase in seed-bearing female $A$. altissima is likely to lead to an increase in the distribution range of the species. Yet, the distance to the next seed source was not important for the density of $A$. altissima (Table 4). This may suggest that the density of $A$. altissima is mainly driven by the amount of suitable establishment sites in case seeds are available. Nevertheless, seed addition experiments would be required to quantify the relative importance of seed limitation for the occurrence and density of $A$. altissima in the studied forests (Turnbull et al. 2000).

Vegetation cover, which was excluded from the models due to multicollinearity with light availability and litter cover, was significantly higher at presence points (Fig. 3d). This may contradict the oftentimes reported negative effect of herbs and shrubs on the establishment of tree regeneration (Maguire and Forman 1983; Picon-Cochard et al. 2006). However, as high light availability tends to simultaneously enhance both the amount of vegetation (Vockenhuber et al. 2011) and the probability of occurrence and abundance of $A$. altissima (Tables 3,4 ), high vegetation cover may rather be the consequence of suitable germination conditions. Nevertheless, it is possible that very high vegetation cover $(\geq 75 \%)$ hindered the establishment of $A$. altissima at two sampling points with ample light availability (Fig. 3e, outlier points on the left). Yet, A. altissima regeneration was still present at three out of five sampling points with vegetation cover $\geq 75 \%$, probably owed to its fast juvenile height growth (Knapp and Canham 2000; Martin et al. 2010). Hence, we surmise that the role of vegetation cover for the establishment of $A$. altissima may be different depending on the timing of its development and its coincidence with seed rain.

We did not consider soil characteristics as A. altissima is known to tolerate a broad range of soil conditions (Kowarik and Säumel 2007). In other studies, A. altissima occurred slightly more often on moister soils (Radtke et al. 2013) and was associated with sites with high indicator values for nutrients (Berg et al. 2017). However, soil characteristics were not identified as the main factors influencing the establishment of $A$. altissima.

\section{Browsing and fraying}

Ailanthus altissima suffered almost no damage from ungulate browsing compared to cooccurring regeneration (Fig. 4), which agrees with findings of Maringer et al. (2012). We hypothesize that browsing may enhance the establishment success of $A$. altissima through reduced competition by co-occurring regeneration, as suggested by the abundance models. Reduced herbivory by ungulates or insects is common for many novel non-native species and may influence successional pathways of colonised forest stands (Cappuccino and Carpenter 2005; Knapp et al. 2008). However, differences in herbivore damage are thought to decrease with time since introduction (Brändle et al. 2008; Schilthuizen et al. 
2016). Furthermore, results from Hungary (Mátrai et al. 2004) and the USA (Hunter 1995; Carter and Fredericksen 2007) demonstrate that $A$. altissima is sometimes browsed as frequently as co-occurring trees. In addition, fraying damages on larger regeneration, which were to our knowledge considered for the first time in this study, were as frequent on A. altissima as on other species (Fig. S2). However, fraying did not seem to cause mortality, as several saplings with sealing callus growth and wound closure were found. This is in line with findings of Gurtner (2015) in the study region.

\section{Comparison with post-fire establishment}

Forest fires temporarily increase the availability of light and nutrients, and reduce competition (Tyler and D'Antonio 1995; Keeley et al. 2003), which tends to promote the establishment of $A$. altissima (Maringer et al. 2012; Crandall and Knight 2018). These same factors, i.e. high light availability and reduced competition via high rock cover or browsing on competing regeneration were also important for the establishment of $A$. altissima in recently undisturbed forests analysed here. Furthermore, low litter cover seemed to be similarly important for the establishment of $A$. altissima after a fire and in recently undisturbed forests. Moreover, A. altissima seems to benefit from the higher availability of mineral soil after a fire for its establishment. Based on the similar patterns in the establishment drivers of $A$. altissima in fire-disturbed and recently undisturbed forests (Fig. 3), we conclude that $A$. altissima follows the same establishment strategy in both cases. This is in line with findings of Martin et al. (2010), who suggest that A. altissima is restricted by a trade-off between low light survivorship and high light growth also when growing in closed-canopy forests, unlike other non-native tree species such as Acer platanoides L. (Martin and Marks 2006; Martin et al. 2010; Shouman et al. 2017). While early generative regeneration of A. altissima may only persist for an average of three years at low light levels ( $<5 \%$ GLI; Martin et al. 2010; Knüsel et al. 2016), A. platanoides showed almost no mortality at such light levels after five years (Martin et al. 2010), but was still able to grow at similar rates once released from shade (Martin and Marks 2006; Martin et al. 2010; Shouman et al. 2017). However, the strong vegetative regeneration potential of $A$. altissima, which was not considered in this study, may enable the species to increase its persistence in unfavourable conditions after it successfully established in a forest stand (Kowarik 1995; Knüsel et al. 2016).

\section{Interactions with other species}

Due to the early successional character of both $A$. altissima and $R$. pseudoacacia (Radtke et al. 2013; Berg et al. 2017), we expected a positive interaction between these species, as observed by Call and Nilsen (2003). However, only seedlings but not saplings of $R$. pseudoacacia were positively associated with $A$. altissima saplings (Tables S5, S6). This may be related to the high browsing pressure on $R$. pseudoacacia (Fig. 4) that may have strongly reduced the number of saplings of $R$. pseudoacacia (Fig. 2). 


\section{Future development of analysed forest stands}

The increasing relative abundance of $A$. altissima with increasing development stage (Fig. 2) suggests that the fraction of basal area of $A$. altissima will increase in the analysed forests. Several factors may further favour the future establishment and spread of $A$. altissima. First, an increase in the number of seed-bearing trees may augment both the occurrence and abundance of A. altissima, as the dispersal of non-native species is oftentimes limited by propagule pressure (Křivánek et al. 2006; Edward et al. 2009). Second, ungulate browsing may continue to act stronger on co-occurring species, thereby reducing understorey competition for $A$. altissima. Third, natural disturbances such as fire, windthrow or uprooting are expected to increase with climate change (Vogt et al. 2006; Pezzatti et al. 2016), thus creating suitable establishment conditions for $A$. altissima (Martin et al. 2010). Fourth, the high drought tolerance of A. altissima already at the sapling stage (Trifilò et al. 2004) may make this species less vulnerable to anticipated prolonged droughts (CH2011 2011; Lindner et al. 2010). Yet, this study only focused at the first generation of $A$. altissima. The transition from the first established canopy trees to the next generation can be particularly important for future forest succession, as seen for declining early-successional $R$. pseudoacacia in northern Italy (Motta et al. 2009).

\section{Conclusions}

High light availability, low litter cover and to a lesser degree high rock cover resulted as the most important factors determining the occurrence and abundance of A. altissima regeneration in forests lacking of recent large scale disturbances like fire or coppice management (research question i). Interestingly, very similar factors were also important for the establishment of $A$. altissima after a disturbance (research question ii), suggesting a consistent establishment strategy across sites with different disturbance intensities. Thus, light availability remains a key factor that controls the establishment and spread of the species, particularly for generative regeneration analysed in this study.

\section{Acknowledgements}

We thank Florim Sabani, Anna Katharina Calmet, Vanessa Ingold and Laura Jirjahn for field assistance. Further, we thank Boris Pezzatti, Patrick Schleppi and Janet Maringer for help with data processing and analysis. We further thank Eric Gehring and Janet Maringer for helpful discussions on earlier versions of the manuscript and Luca Plozza for information on the study sites. This study was funded by the Swiss National Science Foundation (SNF) and the French National Research Agency (ANR) (Project-Nr: 310030L_156661), the Federal Office for the Environment (FOEN) and the Swiss Federal Research Institute for Forest, Snow and Landscape Research (WSL). 


\section{References}

Bartoń K (2018) MuMIn: Multi-Model Inference. R package version: 1.40.4

Berg C, Drescherl A, Essl F (2017) Using releve-based metrics to explain invasion patterns of alien trees in temperate forests. Tuexenia 37: 127-142. https://doi.org/10.14471/2017.37.012

Blaser P, Zimmermann S, Luster J, Walthert L, Lüscher P (2005) Waldböden der Schweiz. Band 2. Regionen Alpen und Alpensüdseite. Birmensdorf, Eidg. Forschungsanstalt für Wald, Schnee und Landschaft WSL; Hep Verlag, Bern, 920 pp.

Brändle M, Kühn I, Klotz S, Belle C, Brandl R (2008) Species richness of herbivores on exotic host plants increases with time since introduction of the host. Diversity and Distributions 14: 905-912. https://doi.org/10.1111/j.1472-4642.2008.00511.x

Burnham KP, Anderson DR (2002) Model Selection and Multimodel Inference. Springer, New York, 485 pp. https://doi.org/10.1007/b97636

Call LJ, Nilsen ET (2003) Analysis of spatial patterns and spatial association between the invasive tree-of-heaven (Ailanthus altissima) and the native black locust (Robinia pseudoacacia). American Midland Naturalist 150: 1-14. https://doi.org/10.1674/00030031(2003)150[0001:AOSPAS]2.0.CO;2

Cappuccino N, Carpenter D (2005) Invasive exotic plants suffer less herbivory than non-invasive exotic plants. Biology Letters 1: 435-438. https://doi.org/10.1098/rsbl.2005.0341

Carter WK, Fredericksen TS (2007) Tree seedling and sapling density and deer browsing incidence on recently logged and mature non-industrial private forestlands in Virginia, USA. Forest Ecology and Management 242: 671-677. https://doi.org/10.1016/j. foreco.2007.01.086

Celesti-Grapow L, Blasi C (2004) The role of alien and native weeds in the deterioration of archaeological remains in Italy. Weed Technology 18: 1508-1513. https://doi. org/10.1614/0890-037X(2004)018[1508:TROAAN]2.0.CO;2

CH2011 (2011) Swiss Climate Change Scenarios CH2011. C2SM, MeteoSwiss, ETH, NCCR Climate, and OcCC, Zurich, 88 pp.

Closset-Kopp D, Chabrerie O, Valentin B, Delachapelle H, Decocq G (2007) When Oskar meets Alice: Does a lack of trade-off in $\mathrm{r} / \mathrm{K}$-strategies make Prunus serotina a successful invader of European forests? Forest Ecology and Management 247: 120-130. https://doi. org/10.1016/j.foreco.2007.04.023

Conedera M, Manetti MC, Giudici F, Amorini E (2004) Distribution and economic potential of the Sweet chestnut (Castanea sativa Mill.) in Europe. Ecologia Mediterranea 30: 15.

Conedera M, Stanga P, Oester B, Bachmann P (2001) Different post-culture dynamics in abandoned chestnut orchards and coppices. Forest Snow and Landscape Research 76: 487-492.

Conedera M, Wohlgemuth T, Tanadini M, Pezzatti GB (2017) Drivers of broadleaved evergreen species spread into deciduous forests in the southern Swiss Alps. Regional Environmental Change 18: 425-436. https://doi.org/10.1007/s10113-017-1212-7

Crandall RM, Knight TM (2018) Role of multiple invasion mechanisms and their interaction in regulating the population dynamics of an exotic tree. Journal of Applied Ecology 55: 885-894. https://doi.org/10.1111/1365-2664.13020 
Dyderski MK, Jagodziński AM (2018) Drivers of invasive tree and shrub natural regeneration in temperate forests. Biological Invasions 20: 2363-2379. https://doi.org/10.1007/ s10530-018-1706-3

Edward E, Munishi PKT, Hulme PE (2009) Relative roles of disturbance and propagule pressure on the invasion of humid tropical forest by Cordia alliodora (Boraginaceae) in Tanzania. Biotropica 41: 171-178. https://doi.org/10.1111/j.1744-7429.2008.00474.x

Essl F, Milasowszky N, Dirnbock T (2011) Plant invasions in temperate forests: Resistance or ephemeral phenomenon? Basic and Applied Ecology 12: 1-9. https://doi.org/10.1016/j. baae.2010.10.003

Facelli JM (1994) Multiple indirect effects of plant litter affect the establishment of woody seedlings in old fields. Ecology 75: 1727-1735. https://doi.org/10.2307/1939632

Facelli JM, Pickett STA (1991) Indirect effects of litter on woody seedlings subject to herb competition. Oikos 62: 129-138. https://doi.org/10.2307/3545257

Fisichelli NA, Frelich LE, Reich PB (2013) Climate and interrelated tree regeneration drivers in mixed temperate-boreal forests. Landscape Ecology 28: 149-159. https://doi.org/10.1007/ s10980-012-9827-z

Fox J, Weisberg S (2011) An R Companion to Applied Regression. Sage, Thousand Oaks, CA. Frelich LE, Reich PB (2002) Dynamics of old-growth oak forests in the eastern United States. In: McShea WJ, Healy WM (Eds) Oak Forest Ecosystems: Ecology and Management for Wildlife. Johns Hopkins University Press, Baltimore, 113-128.

Fuentes-Ramírez A, Pauchard A, Cavieres LA, García RA (2011) Survival and growth of Acacia dealbata vs. native trees across an invasion front in south-central Chile. Forest Ecology and Management 261: 1003-1009. https://doi.org/10.1016/j.foreco.2010.12.018

Gehring E, Bellosi B, Quacchia A, Conedera M (2017) Assessing the impact of Dryocosmus kuriphilus on the chestnut tree: branch architecture matters. Journal of Pest Science 91: 189-202. https://doi.org/10.1007/s10340-017-0857-9

Gonsamo A, D’Odorico P, Pellikka P (2013) Measuring fractional forest canopy element cover and openness - definitions and methodologies revisited. Oikos 122: 1283-1291. https:// doi.org/10.1111/j.1600-0706.2013.00369.x

Gret-Regamey A, Brunner SH, Altwegg J, Bebi P (2013) Facing uncertainty in ecosystem servicesbased resource management. Journal of Environmental Management 127(Supplement): S145-154. https://doi.org/10.1016/j.jenvman.2012.07.028

Grund K, Conedera M, Schröder H, Walther GR (2005) The role of fire in the invasion process of evergreen broad-leaved species. Basic and Applied Ecology 6: 47-56. https://doi. org/10.1016/j.baae.2004.07.005

Gurtner D (2015) Distribution and Environmental Niche of Invasive Ailanthus altissima in Switzerland. ETH Zurich, Zurich, 82 pp.

Gurtner D, Conedera M, Rigling A, Wunder J (2015) Der Götterbaum dringt in die Wälder nördlich der Alpen vor. Wald und Holz 7: 22-24.

Heuret P, Guédon Y, Guérard N, Barthélémy D (2003) Analysing branching pattern in plantations of young red oak trees (Quercus rubra L., Fagaceae). Annals of Botany 91: 479-492. https://doi.org/10.1093/aob/mcg046 
Hickler T, Vohland K, Feehan J, Miller PA, Smith B, Costa L, Giesecke T, Fronzek S, Carter TR, Cramer W, Kuhn I, Sykes MT (2012) Projecting the future distribution of European potential natural vegetation zones with a generalized, tree species-based dynamic vegetation model. Global Ecology and Biogeography 21: 50-63. https://doi.org/10.1111/j.1466-8238.2010.00613.x

Höfle R, Dullinger S, Essl F (2014) Different factors affect the local distribution, persistence and spread of alien tree species in floodplain forests. Basic and Applied Ecology 15: 426434. https://doi.org/10.1016/j.baae.2014.07.007

Huebner CD, Regula AE, McGill DW (2018) Germination, survival, and early growth of three invasive plants in response to five forest management regimes common to US northeastern deciduous forests. Forest Ecology and Management 425: 100-118. https://doi. org/10.1016/j.foreco.2018.05.037

Hunter JC (1995) Ailanthus altissima: its biology and recent history. CalEPPC News 3: 4-5.

Jennings SB, Brown ND, Sheil D (1999) Assessing forest canopies and understorey illumination: canopy closure, canopy cover and other measures. Forestry 72: 59-73. https://doi. org/10.1093/forestry/72.1.59

Kasson MT, Davis MD, Davis DD (2013) The invasive Ailanthus altissima in Pennsylvania: a case study elucidating species introduction, migration, invasion, and growth patterns in the northeastern US. Northeastern Naturalist 20: 1-60.

Keeley JE, Lubin D, Fotheringham CJ (2003) Fire and grazing impacts on plant diversity and alien plant invasions in the southern Sierra Nevada. Ecological Applications 13: 13551374. https://doi.org/10.1890/02-5002

Knapp LB, Canham CD (2000) Invasion of an old-growth forest in New York by Ailanthus altissima: sapling growth and recruitment in canopy gaps. Journal of the Torrey Botanical Society 127: 307-315. https://doi.org/10.2307/3088649

Knapp LB, Fownes JH, Harrington RA (2008) Variable effects of large mammal herbivory on three non-native versus three native woody plants. Forest Ecology and Management 255: 92-98. https://doi.org/10.1016/j.foreco.2007.08.023

Knüsel S, De Boni A, Conedera M, Schleppi P, Thormann J-J, Frehner M, Wunder J (2016) Shade tolerance of Ailanthus altissima revisited: novel insights from southern Switzerland. Biological Invasions 19: 455-461. https://doi.org/10.1007/s10530-016-1301-4

Kostel-Hughes F, Young TP, Wehr JD (2005) Effects of leaf litter depth on the emergence and seedling growth of deciduous forest tree species in relation to seed size. Journal of the Torrey Botanical Society 132: 50-61. https://doi.org/10.3159/1095-5674(2005)132[50:EOLLD $\mathrm{O}] 2.0 . \mathrm{CO} ; 2$

Kowarik I (1995) Clonal growth in Ailanthus altissima on a natural site in West Virginia. Journal of Vegetation Science 6: 853-856. https://doi.org/10.2307/3236399

Kowarik I, Säumel I (2007) Biological flora of Central Europe: Ailanthus altissima (Mill.) Swingle. Perspectives in Plant Ecology Evolution and Systematics 8: 207-237. https://doi. org/10.1016/j.ppees.2007.03.002

Křivánek M, Pyšek P, Jarošík V (2006) Planting history and propagule pressure as predictors of invasion by woody species in a temperate region. Conservation Biology 20: 1487-1498. https://doi.org/10.1111/j.1523-1739.2006.00477.x 
Lindner M, Fitzgerald JB, Zimmermann NE, Reyer C, Delzon S, van der Maaten E, Schelhaas MJ, Lasch P, Eggers J, van der Maaten-Theunissen M, Suckow F, Psomas A, Poulter B, Hanewinkel M (2014) Climate change and European forests: what do we know, what are the uncertainties, and what are the implications for forest management? Journal of Environmental Management 146: 69-83. https://doi.org/10.1016/j. jenvman.2014.07.030

Lindner M, Maroschek M, Netherer S, Kremer A, Barbati A, Garcia-Gonzalo J, Seidl R, Delzon S, Corona P, Kolstrom M, Lexer MJ, Marchetti M (2010) Climate change impacts, adaptive capacity, and vulnerability of European forest ecosystems. Forest Ecology and Management 259: 698-709. https://doi.org/10.1016/j.foreco.2009.09.023

Maguire DA, Forman RTT (1983) Herb cover effects on tree seedling patterns in a mature hemlock-hardwood forest. Ecology 64: 1367-1380. https://doi.org/10.2307/1937491

Maringer J, Wohlgemuth T, Neff C, Pezzatti GB, Conedera M (2012) Post-fire spread of alien plant species in a mixed broad-leaved forest of the Insubric region. Flora 207: 19-29. https://doi.org/10.1016/j.flora.2011.07.016

Martin PH, Canham CD (2010) Dispersal and recruitment limitation in native versus exotic tree species: life-history strategies and Janzen-Connell effects. Oikos 119: 807-824. https://doi.org/10.1111/j.1600-0706.2009.17941.x

Martin PH, Canham CD, Kobe RK (2010) Divergence from the growth-survival trade-off and extreme high growth rates drive patterns of exotic tree invasions in closed-canopy forests. Journal of Ecology 98: 778-789. https://doi.org/10.1111/j.1365-2745.2010.01666.x

Martin PH, Canham CD, Marks PL (2009) Why forests appear resistant to exotic plant invasions: intentional introductions, stand dynamics, and the role of shade tolerance. Frontiers in Ecology and the Environment 7: 142-149. https://doi.org/10.1890/070096

Martin PH, Marks PL (2006) Intact forests provide only weak resistance to a shade-tolerant invasive Norway maple (Acer platanoides L.). Journal of Ecology 94: 1070-1079. https:// doi.org/10.1111/j.1365-2745.2006.01159.x

Mátrai K, Szemethy L, Tóth P, Katona K, Székely J (2004) Resource use by red deer in lowland nonnative forests, Hungary. Journal of Wildlife Management 68: 879-888. https://doi. org/10.2193/0022-541X(2004)068[0879:RUBRDI]2.0.CO;2

Moser B, Temperli C, Schneiter G, Wohlgemuth T (2010) Potential shift in tree species composition after interaction of fire and drought in the Central Alps. European Journal of Forest Research 129: 625-633. https://doi.org/10.1007/s10342-010-0363-6

Motta R, Nola P, Berretti R (2009) The rise and fall of the black locust (Robinia pseudoacacia L.) in the "Siro Negri" Forest Reserve (Lombardy, Italy): lessons learned and future uncertainties. Annals of Forest Science 66: 410. https://doi.org/10.1051/forest/2009012

Nakagawa S, Freckleton RP (2010) Model averaging, missing data and multiple imputation: a case study for behavioural ecology. Behavioral Ecology and Sociobiology 65: 103-116. https://doi.org/10.1007/s00265-010-1044-7

Nathan R, Muller-Landau HC (2000) Spatial patterns of seed dispersal, their determinants and consequences for recruitment. Trends in Ecology \& Evolution 15: 278-285. https://doi. org/10.1016/S0169-5347(00)01874-7 
O’Neal ES, Davis DD (2015) Intraspecific Root Grafts and Clonal Growth Within Ailanthus altissima Stands Influence Verticillium nonalfalfae Transmission. Plant Disease 99: 10701077. https://doi.org/10.1094/PDIS-07-14-0722-RE

Pezzatti GB, De Angelis A, Conedera M (2016) Potenzielle Entwicklung der Waldbrandgefahr im Klimawandel. In: Pluess AR, Augustin S, Brang P (Eds) Wald im Klimawandel: Grundlagen für Adaptationsstrategien. Bundesamt für Umwelt BAFU, Eidgenössische Forschungsanstalt für Wald, Schnee und Landschaft WSL, Bern, Stuttgart, Wien: Haupt, 223-245.

Picon-Cochard C, Coll L, Balandier P (2006) The role of below-ground competition during early stages of secondary succession: the case of 3-year-old Scots pine (Pinus sylvestris L.) seedlings in an abandoned grassland. Oecologia 148: 373-383. https://doi.org/10.1007/ s00442-006-0379-2

Pividori M, Armando F, Conedera M (2005) Post cultural dynamics in a mixed chestnut coppice at its ecological border. Proceedings of the third International Symposium on Chestnut Acta Hortic 693: 219-224. https://doi.org/10.17660/ActaHortic.2005.693.26

Plieninger T, Rolo V, Moreno G (2010) Large-scale patterns of Quercus ilex, Quercus suber, and Quercus pyrenaica regeneration in Central-Western Spain. Ecosystems 13: 644-660. https://doi.org/10.1007/s10021-010-9345-2

Prospero S (2017) Il mal dell'inchiostro del castagno: una malattia in espansione? Forestaviva 68: 26-27.

Pyšek P, Křivánek M, Jarošík V (2009) Planting intensity, residence time, and species traits determine invasion success of alien woody species. Ecology 90: 2734-2744. https://doi. org/10.1890/08-0857.1

Radtke A, Ambrass S, Zerbe S, Tonon G, Fontana V, Ammer C (2013) Traditional coppice forest management drives the invasion of Ailanthus altissima and Robinia pseudoacacia into deciduous forests. Forest Ecology and Management 291: 308-317. https://doi. org/10.1016/j.foreco.2012.11.022

Rebbeck J, Hutchinson T, Iverson L, Yaussy D, Fox T (2017) Distribution and demographics of Ailanthus altissima in an oak forest landscape managed with timber harvesting and prescribed fire. Forest Ecology and Management 401: 233-241. https://doi.org/10.1016/j. foreco.2017.06.050

Rigling A, Bigler C, Eilmann B, Feldmeyer-Christe E, Gimmi U, Ginzler C, Graf U, Mayer P, Vacchiano G, Weber P, Wohlgemuth T, Zweifel R, Dobbertin M (2013) Driving factors of a vegetation shift from Scots pine to pubescent oak in dry Alpine forests. Global Change Biology 19: 229-240. https://doi.org/10.1111/gcb.12038

Rigling D, Prospero S (2018) Cryphonectria parasitica, the causal agent of chestnut blight: invasion history, population biology and disease control. Molecular Plant Pathology 19: 7-20. https://doi.org/10.1111/mpp.12542

Robin X, Turck N, Hainard A, Tiberti N, Lisacek F, Sanchez JC, Muller M (2011) pROC: an open-source package for $\mathrm{R}$ and $\mathrm{S}+$ to analyze and compare ROC curves. BMC Bioinformatics 12: 77. https://doi.org/10.1186/1471-2105-12-77

Schilthuizen M, Santos Pimenta LP, Lammers Y, Steenbergen PJ, Flohil M, Beveridge NG, van Duijn PT, Meulblok MM, Sosef N, van de Ven R, Werring R, Beentjes KK, Meijer K, 
Vos RA, Vrieling K, Gravendeel B, Choi Y, Verpoorte R, Smit C, Beukeboom LW (2016) Incorporation of an invasive plant into a native insect herbivore food web. PeerJ 4: e1954. https://doi.org/10.7717/peerj.1954

Schleppi P, Conedera M, Sedivy I, Thimonier A (2007) Correcting non-linearity and slope effects in the estimation of the leaf area index of forests from hemispherical photographs. Agricultural and Forest Meteorology 144: 236-242. https://doi.org/10.1016/j.agrformet.2007.02.004

Seidl R, Spies TA, Peterson DL, Stephens SL, Hicke JA (2016) Searching for resilience: addressing the impacts of changing disturbance regimes on forest ecosystem services. Journal of Applied Ecology 53: 120-129. https://doi.org/10.1111/1365-2664.12511

Shields JM, Webster CR, Nagel LM (2007) Factors influencing tree species diversity and Betula alleghaniensis establishment in silvicultural openings. Forestry 80: 293-307. https://doi. org/10.1093/forestry/cpm013

Shouman S, Mason N, Kichey T, Closset-Kopp D, Heberling JM, Kobeissi A, Decocq G (2017) Functional shift of sycamore maple (Acer pseudoplatanus) towards greater plasticity and shade tolerance in its invasive range. Perspectives in Plant Ecology Evolution and Systematics 29: 30-40. https://doi.org/10.1016/j.ppees.2017.11.001

Soják D, Löffler A (1988) Augmentation of increment and dendromass production of Ailanthus altissima SWINGLE by fertilization. Lesnícky časopis 34: 399-412.

Sullivan MJP, Franco AMA (2017) Changes in habitat associations during range expansion: disentangling the effects of climate and residence time. Biological Invasions 20: 1147-1159. https://doi.org/10.1007/s10530-017-1616-9

Terwei A, Zerbe S, Zeileis A, Annighöfer P, Kawaletz H, Mölder I, Ammer C (2013) Which are the factors controlling tree seedling establishment in north Italian floodplain forests invaded by non-native tree species? Forest Ecology and Management 304: 192-203. https://doi.org/10.1016/j.foreco.2013.05.003

Tinner R, Stalder A, Brang P (2010) Aufnahmemethode für Kernflächen in schweizerischen Naturwaldreservaten. Eidg. Forschungsanstalt für Wald, Schnee und Landschaft, WSL, Birmensdorf, 38 pp.

Tinner W, Hubschmid P, Wehrli M, Ammann B, Conedera M (1999) Long-term forest fire ecology and dynamics in southern Switzerland. Journal of Ecology 87: 273-289. https:// doi.org/10.1046/j.1365-2745.1999.00346.x

Trifilò P, Raimondo F, Nardini A, Lo Gullo MA, Salleo S (2004) Drought resistance of Ailanthus altissima: root hydraulics and water relations. Tree Physiology 24: 107-114. https://doi. org/10.1093/treephys/24.1.107

Turnbull LA, Crawley MJ, Rees M (2000) Are plant populations seed-limited? A review of seed sowing experiments. Oikos 88: 225-238. https://doi.org/10.1034/j.16000706.2000.880201.x

Tyler CM, D'Antonio CM (1995) The effects of neighbors on the growth and survival of shrub seedlings following fire. Oecologia 102: 255-264. https://doi.org/10.1007/BF00333258

Vanhellemont M, Baeten L, Hermy M, Verheyen K (2009) The seedling bank stabilizes the erratic early regeneration stages of the invasive Prunus serotina. Ecoscience 16: 452-460. https://doi.org/10.2980/16-4-3285 
Vockenhuber EA, Scherber C, Langenbruch C, Meissner M, Seidel D, Tscharntke T (2011) Tree diversity and environmental context predict herb species richness and cover in Germany's largest connected deciduous forest. Perspectives in Plant Ecology Evolution and Systematics 13: 111-119. https://doi.org/10.1016/j.ppees.2011.02.004

Vogt J, Fonti P, Conedera M, Schroder B (2006) Temporal and spatial dynamic of stool uprooting in abandoned chestnut coppice forests. Forest Ecology and Management 235: 88-95. https://doi.org/10.1016/j.foreco.2006.08.008

Wangen SR, Webster CR (2006) Potential for multiple lag phases during biotic invasions: reconstructing an invasion of the exotic tree Acer platanoides. Journal of Applied Ecology 43: 258-268. https://doi.org/10.1111/j.1365-2664.2006.01138.x

Xi W (2008) Hurricane effects on the Piedmont forests: patterns and implications. Ecological Restoration 26: 295-298. https://doi.org/10.3368/er.26.4.295

Zouhar K, Smith JK, Sutherland S (2008) Effects of fire on nonnative invasive plants and invasibility of wildland ecosystems. In: Zouhar K, Smith JK, Sutherland S, Brooks ML (Eds) Wildland Fire in Ecosystems: Fire and Nonnative Invasive Plants. U.S. Department of Agriculture, Forest Service, Rocky Mountain Research Station, Ogden, Utah, 7-32. https://doi.org/10.2737/RMRS-GTR-42-V6

\section{Supplementary material I}

\section{Justification for models used on the abundance of $A$. altissima}

Authors: Simon Knüsel, Marco Conedera, Harald Bugmann, Jan Wunder

Data type: (models)

Explanation note: We used models with a negative binomial distribution to characterize the abundance of $A$. altissima saplings.

Copyright notice: This dataset is made available under the Open Database License (http://opendatacommons.org/licenses/odbl/1.0/). The Open Database License $(\mathrm{ODbL})$ is a license agreement intended to allow users to freely share, modify, and use this Dataset while maintaining this same freedom for others, provided that the original source and author(s) are credited.

Link: https://doi.org/10.3897/neobiota.46.35722.suppl1 